\title{
Farklı yetiştirme ortamlarının adaçayında (Salvia officinalis L.) tohum çimlenmesi ve fide kalitesi üzerine etkileri
}

Effect of different growth media on germination and seedling quality of sage (Salvia officinalis L.) seeds

\author{
Ramazan ilhan AYTEKiN ${ }^{1 / D}$, Mustafa AKKAMIŞ ${ }^{1}(\mathbb{D})$, Mehmet BEDiR ${ }^{2}$ (i), Sevgi ÇALIŞKAN ${ }^{1 / D}$ \\ ${ }^{1}$ Niğde Ömer Halisdemir Üniversitesi, Ayhan Şahenk Tarım Bilimleri ve Teknolojileri Fakültesi Bitkisel Üretim ve Teknolojileri Bölümü, \\ Merkez, Niğde, 51240, Türkiye. \\ ${ }^{2}$ Sivas Bilim ve Teknoloji Üniversitesi Tarım Bilimleri ve Teknolojileri Fakültesi Bitkisel Üretim ve Teknolojileri Bölümü Sivas, Türkiye.
}

MAKALE BILGISI / ARTICLE INFO

Makale tarihçesi / Article history:

DOI: $10.37908 /$ mkutbd.956193

Geliş tarihi /Received:22.06.2021

Kabul tarihi/Accepted:10.08.2021

\section{Keywords:}

Salvia officinalis, peat, germination ratio, SPAD.

\footnotetext{
Corresponding author: Sevgi ÇALIŞKAN

$\bowtie$ : scaliskan@ohu.edu.tr
}

\section{ÖZET / A B STRACT}

\begin{abstract}
Aims: This study aimed to determine the effect of different growth media on germination performance with seedling quality of Sage (Salvia officinalis L.) seeds.

Methods and Results: The study was conducted in 2020 at Greenhouse of Plant Production and Technologies, Faculty of Agricultural Sciences and Technologies, Nigde Omer Halisdemir University. The greenhouse experiment was laid out in the randomized complete block design with three replications and eight different growth media were used for experiment such as peat $(\% 100)$, soil $(\% 100)$, perlite $(\% 100)$, sand $(\% 100)$, peat + soil $(1: 1)$, peat + perlite $(1: 1)$, peat + sand $(1: 1)$, peat + soil + sand + perlite $(1: 1: 1: 1)$. Healthy seedlings were not obtained from soil (\%100), perlite (\%100) and sand (\%100) used as growth media. The highest germination percentage $(88.83 \%)$ and shortest day required for germination (26.60 day) was achieved in peat media. Besides, the highest seedlings heights $(20.37 \mathrm{~cm})$, leaf chlorophyll content (36.63), dry and fresh weight of seedlings ( $3.48 \mathrm{~g}$ ve $0.57 \mathrm{~g}$ ) and dry and fresh weight of roots ( $3.48 \mathrm{~g}$ ve $0.84 \mathrm{~g}$ ) were obtained in peat media.

Conclusions: It was determined that peat gave the best result for sage plant used as growth media in terms of germination and healthy seedlings in comparison to other growth media.

Significance and Impact of the Study: Different growth media were determined to an have influence on seed germination and development of seedlings and roots according to the results obtained in this study. Therefore, it is important to know the necessity for appropriate growth media to produce healthy and quality seedlings of sage. The most appropriate growth media was found peat according to the results obtained from the present study. As conclusion, the production of healthy and quality seedlings is essential for sage productivity. Determination of growth media will contribute to the producer and sustainability of agriculture activities in terms of sage production.
\end{abstract}

Atıf / Citation: Aytekin Ri, Akkamış M, Bedir M, Çalışkan S (2021) Farklı yetiştirme ortamlarının adaçayında (Salvia officinalis L.) tohum çimlenmesi ve fide kalitesi üzerine etkileri. MKU. Tar. Bil. Derg. 26(3) : 610-616. DOI: $10.37908 /$ mkutbd.956193 


\section{GiRiş}

Tıbbi adaçayı (Salvia officinalis L.), Lamiaceae (Ballıbabagiller) familyasından çok yıllık değerli bir uçucu yağ ve baharat bitkisidir. Dünyada Salvia cinsine ait yaklaşık olarak 900 tür bulunmakla birlikte bu türler çoğunlukla Amerika ve Güney-Batı Asya kıtalarında yer almaktadır. Tıbbi adaçayı olarak adlandırılan Salvia officinalis L., dünyada ticari değeri en yüksek adaçayı türüdür. Ülkemiz bünyesinde 97 tür, 4 alttür ve 8 varyete bulunmakta olup, bu türlerin 51 tanesi endemiktir (Bağdat, 2006; Yılmaz ve Gökduman, 2015; Kusaksız, 2019). Ekonomik değere sahip olan adaçayı yaprakları Başer (2000), geçmiş zamanlardan bu yana hastalıkların tedavisinde kullanılmıştır (Baytop, 1999). Nezle ve gripten kaynaklı boğaz rahatsızlıklarında, solunum yolu iltihaplarında Zeybek ve Zeybek (2002), siroz, Alzheimer, kroner kalp hastalıklarında Sarıcı ve ark. (2004), tedavi amaçlı kullanılmakla birlikte yatıştırıcı, ter kesici, idrar söktürücü ve dezenfektan Abacıoğlu (2019) etkilerinin yanısıra, ülkemizde sorun olan tarımsal hastalık (Bozkurt ve ark., 2020) ve zararlılara (Kaya ve ark., 2018) karşı antimicrobiyal ve insektisidal etkilerede sahiptir. Bitkinin söz konusu etkinlikleri, temel olarak toprak üstü aksamda biriken uçucu yağlardan kaynaklanmaktadır (Mossi ve ark., 2011).

Uygun büyüme ortamı ve altlık kullanımı kaliteli üretim için esastır ve doğrudan büyümeyi ve bunun devamında kök sistemini etkiler. Büyüme ortamı sadece büyümenin gerçekleştiği yer değil aynı zamanda bitki büyümesi için besin kaynağı olarak görev alır. İyi bir büyüme ortamı bitkiye destek sağlamasının yanında su ve besin maddesi için kaynak görevi görür. Ayrıca, köklerde difüzyona izin verir ve kök ile kökün dışındaki atmosfer arasında gaz alışverişini sağlar. Kullanılan ortamın içeriği fide kalitesini etkiler (Wilson ve ark., 2001). Büyüme ortamı tohum çimlenmesi üzerine de büyük rol oynar. Tohum çimlenmesinde kullanılan ortam fide kalitesini, kaliteli fide ise tarlaya şaşırtıldığında tutma oranını ve tarlanın nihai verimliliğini etkiler.

Adaçayı bitkisinin çelikle vejetatif olarak veya tohumla generatif olarak kültürü yapılmaktadır. Tohumla üretimde tohumlar iyi hazırlanmış tarlaya doğrudan ekilebildiği Bağdat (2006), gibi kontrollü koşullarda uygun yetiştirme ortamı ile fide üretimi yapılmakta ve fideler tarlaya dikilmektedir. Organik ve inorganik yetişme ortamlarının seçiminin iyi yapılması, başarılı bir fide üretiminde anahtar rol üstlenmektedir. Farklı oranlarda kullanılan yetişme ortamı karışımları (silt, yaprak kompostu, çiftlik gübresi, cocopeat ve perlit), ortamların bitkilerin fizyolojik ve morfolojik özellikleri üzerine önemli etkileri olduğu bildirilmektedir (Hussain ve ark., 2016). Üretimi yapılan fidelerin kaliteli olması aynı ürünün verim ve kaliteli olmasıyla doğrudan ilişkili olmakla birlikte fide üretiminde kullanılan ortamlar da fide gelişimini ve üretim maliyetini doğrudan etkilemektedir (Yılmaz ve Kınay, 2016). Bu amaçla, son yıllarda çimlenme sorununun çözümüne yönelik çalışmalar ile fide kalitesinin iyileştirilmesine yönelik çalışmalar önem kazanmıştır. Önceki araştırıcılar tarafından farklı büyüme ortamları ve farklı bitkilerde yürütülmüş çalışmalar mevcuttur. López Castro ve ark. (2008), yapmış oldukları bir çalışmada tıbbi adaçayı bitkisinin yüksek organik madde içeriğine sahip toprak ve kayın mantarı kullanılmış karışımdan oluşan farklı yetiştirme ortamlarının kullanılmasının, kontrol grubuna kıyasla büyüme ve gelişmelerinde olumlu sonuç aldıklarını bildirmişlerdir. Kaçar ve ark. (2009), 1000 ppm IBA ile muamele edilmiş iki adaçayı türünü (Salvia officinalis L. ve Salvia triloba L.) üç farklı yetiştirme ortamında (\% 100 torf, $\% 80$ torf $+\% 20$ perlit, $\% 80$ torf + \% 20 süngertaşı) köklendirmişler, araştırma sonucunda Salvia officinalis L.'nin (\% 72.16) Salvia triloba L.'den (\% 57.22) daha yüksek köklenme yüzdesi elde edildiğini, \% 80 torf $+\% 20$ süngertaşı ve $\% 80$ torf +20 perlit içeren ortamda en iyi köklenme yüzdesinin gerçekleştiğini ve ayrıca Salvia officinalis L.'den yüksek bir kök kuru ağırlığı elde edildiğini bildirmişlerdir. Sapar (2019), S. aramiensis Rech. fil. türünün çelikle çoğaltılma olanaklarını belirlemek amacıyla 4 farklı zamanda (Mart, Nisan, Mayıs, Haziran) çelikler almış, çeliklere, farklı dozlarda (kontrol-0, 250, 500, 1000 ppm) Indol-3 Bütirik Asit (IBA) uygulamıştır Çalışma sonucunda, en yüksek köklenme oranının Nisan ayında alınan ve 500 ppm IBA uygulanan çeliklerden, en fazla kök sayısının Mart ayında alınan ve 1000 ppm IBA uygulanan çeliklerden ve en uzun köklü çeliklerin Nisan ayında alınan ve 1000 ppm IBA uygulanan çeliklerden elde ettiğini bildirmiştir. Boyle ve Craker (1991), biberiye bitkisini topraklı (1 turba: 1 perlit: 1 tarla toprağı) ve topraksız ( 1 turba: 1 perlit) ortamda yetiştirmiş; toprak esaslı karışımda yetiştirilen bitkilerin, topraksız karışımda yetiştirilen bitkilere göre daha kısa, sürgün yaş ve kuru ağılıklarının daha düşük ve uçucu yağ veriminin daha yüksek olduğunu bildirmişlerdir. Kösa ve Karagüzel (2012), büyüme ortamı olarak kullandıkları torf+kum (2:1), torf+perlit (2:1) ve toprak+çiftlik gübresi+kum (2:1:1) karışımlarının Alnus orientalis fidanlarında en yüksek fidan boyu, gövde çapı, yaprak sayısı, yan dal sayısı ve uzunluğu, gövde ve kök kuru ağırlık değerlerini toprak+çiftlik gübresi+kum (2:1:1) karışımından tespit ettiklerini bildirmişlerdir. Polat ve ark. (2017), yapmış oldukları çalışmada 5 farklı yetiştirme ortamının (cibre, torf, perlit, torf+perlit (1:1) ve bahçe toprağı) Crimson Sweet karpuz çeşidinin fide kalitesi 
üzerine etkilerini araştırdıkları çalışmada fide büyümesi bakımından en iyi sonuç veren yetiştirme ortamının torf:perlit (1:1) olduğu sonucuna varmışlardır. Dolayısıyla adaçayı yetiştiriciliğinde sağlıklı ve kaliteli fide üretmek, yüksek verimlilik için en önemli tarım uygulamalarından biridir (Zawiślak ve Dyduch, 2003).

Bu çalışmada, farklı altık kullanılarak oluşturulan yetiştirme ortamlarının tıbbi adaçayı (Salvia officinalis L.) tohumlarında çimlenme performansı ile fide kalitesi üzerine olan etkilerinin belirlenmesi amaçlanmıştır.

\section{MATERYAL ve YÖNTEM}

Araştırma 2020 yılında Niğde Ömer Halisdemir Üniversitesi Tarım Bilimleri ve Teknolojileri Fakültesi Bitkisel Üretim ve Teknolojileri Bölümü'ne ait uygulama serasında yürütülmüştür. Çalışmada yetiştirme ortamı olarak torf (\%100), toprak (\%100), perlit (\%100), kum (\%100), torf+toprak (1:1), torf+perlit (1:1), torf+kum (1:1), torf+toprak+kum+perlit (1:1:1:1) olacak şekilde sekiz farklı uygulama yer almıştır. Yetiştirme ortamları belirtilen oranlarda hazırlanmış ve alt, üst ve yükseklik çapları sırasıyla 4-6-6 cm olan viyollere doldurulmuştur. Bitkisel materyal olarak tercih edilen tıbbi adaçayı (Salvia officinalis L.) tohumları Erciyes Üniversitesi Seyrani Ziraat Fakültesi'nden temin edilmiştir. S. officinalis L. türüne ait tohumlar hazırlanan ortamlara yaklaşık $1 \mathrm{~cm}$ derinliğe denk gelecek şekilde 13 Mart 2020 tarihinde ekilmiştir. Tesadüf parselleri deneme desenine göre 3 tekerrürlü olarak yürütülen denemede her parselde 54 adet tohum kullanılmıştır.

Tohum ekiminden itibaren yetiştirme ortamının nemi her gün sabah ve akşamüstü kontrol edilerek ihtiyaç duyulan miktarda sulaması yapılmıştır. Deneme süresince bitkilere herhangi bir gübre uygulaması yapılmamıştır. Denemede, ilk çimlenmenin görüldüğü günden itibaren çimlenme gün sayıları not alınmış ve ortalama gün sayısı ile çimlenme oranı hesaplanmıştır. Klorofil (SPAD) ölçümleri, Minolta SPAD 502 Klorofilmetre cihazı kullanılarak bitkinin gelişimini tamamlamıs 3. veya 4. tepe yaprağından yapılmıştır. Deneme 50 gün süreyle takip edilmiş, elde edilen fidelerde bitki boyu, kök uzunluğu, yaprak sayısı, dal sayısı, kök yaş ve kuru ağırlık ile fide yaş ve kuru ağırlık ölçümleri yapılmıştır. Bitkilerde kök ve fide kuru ağırlıklarının hesaplanması için örnekler cam petri kaplarına konmuş ve ağzı cam kapakla kapatılarak $70{ }^{\circ} \mathrm{C}^{\prime}$ de 48 saat bekletildikten sonra alınmış ve tartılmıştır.

Yapılan gözlemler sonucunda elde edilen sonuçlar analizi SPSS paket programı ile yapılmış ve uygulamalar arası farklıı̆ı̆n karşılaştırılmasında LSD (0.05) testinden faydalanılmıştır.

\section{BULGULAR ve TARTIŞMA}

Çalışmada yetiştirme ortamı olarak kullanılan \%100 toprak, \%100 perlit ve \%100 kum uygulamalarında, ekilen tohumların çimlenmesi düzenli olmamıştır. Toprak, perlit ve kum ortamlarında düşük oranlarda çimlenme gerçekleşmiş olmakla birlikte çimlenme sonrasında genç fidecikler yaşamlarını sürdürememişlerdir. En yüksek ortalama çimlenme oranı \%100 perlit uygulamasından (\%67) elde edilmiştir. Bu nedenle, $\% 100$ toprak, $\% 100$ perlit ve $\% 100$ kum ortamlarının tohumdan kaliteli adaçayı fidesi elde edilmesine uygun olmadığı sonucuna varılmış ve denemeden çıkartılmıştır.

Farklı yetiştirme ortamlarının adaçayı tohumlarında çimlenme oranı ve ortalama çimlenme süresi üzerine etkisi Tablo 1'de verilmiştir. Tablo 1 incelendiğinde adaçayı fide üretiminde kullanılan farklı ortamların çimlenme oranı (\%) ve ortalama çimlenme gün sayısı (gün) üzerine etkisi istatistiksel olarak $(P<0,01)$ önemli bulunmuştur. En yüksek çimlenme oranı $\% 88.83$ ile $\% 100$ torf uygulamasından elde edilirken bunu \%88.23 ile torf + toprak uygulaması ile $\% 85.73$ ile torf + perlit uygulamaları takip etmiş ve her iki uygulama da istatistiki olarak aynı grup içerisinde yer almışlardır. En düşük çimlenme oranı \%81.43 ile torf + kum karışımı ve \%83.30 torf + toprak + perlit + kum karışımlarından elde edilmiştir. Çalışmada en kısa çimlenme gün sayısı, torf (26.60 gün) ortamından elde edilmiş olup, torf + toprak (27.30 gün) ortamı ile istatistiksel olarak aynı grupta yer almışlardır. En uzun ortalama çimlenme gün sayısı torf + kum (36.83 gün) ve ile torf + toprak + perlit + kum (36.60 gün) ortamlarından elde edilmiş ve bu ortamlar istatistiki olarak aynı grupta yer almıştır. Torf, çimlenme ve kaliteli fide gelişimi açısından fidecilikte ilk sırada tercih edilen bir materyaldir. Fidecilikte torf ortamına daha ucuz olan perlit ortamının eklenmesi maliyeti düşürür ki bu da önemli bir fayda sağlar. Ayrıca fidecilikte torf kullanılması erkencilik sağlaması, yüksek çimlenme oranı ve kaliteli fide elde edilmesi nedeniyle tercih edilecek malzeme konumundadır (Çelebi, 2019). Çalışmamızda \%100 torf ile torf + toprak ortamları adaçayı tohumlarının çimlenmesinde hem erkencilik sağlaması hem de yüksek çimlenme yüzdesi ile diğer ortamlara göre daha avantajlı ortam olmuştur. Araştırma bulguları Meenu Sood ve ark. (2016) ve Çelebi (2019)'nin elde ettiği sonuçlar ile paralellik göstermiştir. 
Çizelge 1. Farklı yetiştirme ortamlarının adaçayı tohumlarında çimlenme oranı, ortalama çimlenme süresi, yaprak sayısı, fide ve kök uzunluğu üzerine etkileri

Table 1. Effects of different growth media of sage (Salvia officinalis L.) seeds on germination rate, mean germination time, leaf number seedling and root lenght

\begin{tabular}{llllll}
\hline Ortamlar & $\begin{array}{l}\text { Çimlenme Oranı } \\
(\%)\end{array}$ & $\begin{array}{l}\text { Ort. Çimlenme Gün } \\
\text { Sayısı (gün) }\end{array}$ & $\begin{array}{l}\text { Yaprak Sayısı } \\
\text { (adet/bitki) }\end{array}$ & $\begin{array}{l}\text { Fide Uzunluğu } \\
\text { (cm) }\end{array}$ & $\begin{array}{l}\text { Kök Uzunluğu } \\
\text { (cm) }\end{array}$ \\
\hline Torf & $88.83 \mathrm{a}$ & $26.60 \mathrm{a}$ & $9.87 \mathrm{bc}$ & $20.37 \mathrm{a}$ & $21.73 \mathrm{c}$ \\
Torf+Toprak & $88.23 \mathrm{a}$ & $27.30 \mathrm{ab}$ & $11.03 \mathrm{a}$ & $19.43 \mathrm{a}$ & $27.40 \mathrm{~b}$ \\
Torf+Perlit & $85.73 \mathrm{ab}$ & $28.37 \mathrm{~b}$ & $10.53 \mathrm{ab}$ & $17.86 \mathrm{~b}$ & $32.06 \mathrm{a}$ \\
Torf+Kum & $81.43 \mathrm{c}$ & $36.83 \mathrm{c}$ & $9.83 \mathrm{bc}$ & $15.60 \mathrm{c}$ & $25.67 \mathrm{~b}$ \\
$\begin{array}{l}\text { Torf+Toprak+Perlit+Kum } \\
\text { Ortalama }\end{array}$ & $83.30 \mathrm{bc}$ & $36.60 \mathrm{c}$ & $8.83 \mathrm{c}$ & $10.30 \mathrm{~d}$ & $23.73 \mathrm{c}$ \\
$\begin{array}{l}\text { LSD (\%5) } \\
\text { Tekerrür }\end{array}$ & 85.51 & 31.14 & 10.02 & 16.71 & 25.97 \\
Uygulama & 0.572 & 0.346 & 0.057 & 0.058 & 0.239 \\
Hata & & & & & \\
DK (\%) & 0.309 & 0.258 & 0.042 & 0.309 & 4.101 \\
\hline
\end{tabular}

Adaçayı fide üretiminde kullanılan farklı yetiştirme ortamlarının yaprak sayısı (adet/bitki), fide uzunluğu $(\mathrm{cm})$ ve kök uzunluğu $(\mathrm{cm})$ üzerine etkisi istatistiksel olarak $(P<0,01)$ önemli bulunmuştur (Tablo 1.). Torf + toprak ve torf + perlit karışım ortamları istatistiksel olarak aynı grupta yer almakta olup, en yüksek yaprak sayısı 11.03 adet ile torf + toprak karışımından; en düşük yaprak sayısı ise 8.83 adet ile torf + toprak + perlit + kum karışımından elde edilmiştir. Yetiştirme ortamı, bitkide yaprak sayısının artmasında etkili önemli bir faktördür. Yetiştirme ortamındaki yüksek azot ve potasyum varlığı, yaprak sayısında artışa neden olmaktadır (Shahid ve ark., 2017). Cardens ve ark. (2006)'nın yapmış oldukları çalışmada pirinç kabuğu-hindistan cevizi (\%65-\%35) karışımından bitki başına en yüksek yaprak sayısı elde ettiklerini bildirmişlerdir. Bu sonuçlar elde ettiğimiz bulgular ile örtüşmektedir. Fide uzunluğu bakımından torf $(20.37 \mathrm{~cm})$ ve torf + perlit $(19.43 \mathrm{~cm})$ ortamları en yüksek değerleri vermişlerdir (Tablo 1). Çalışmada en düşük fide uzunluk değeri ise $10.30 \mathrm{~cm}$ ile torf + toprak + perlit + kum karışımından elde edilmiştir. Bhardwaj (2014) ve Yılmaz ve Kınay (2016) tarafından Torf ortamının gevşek, süzek ve havadar olması sonucu fidelerin su ve besin maddelerinden daha hızlı yararlanma sağladığı, bunun sonucunda daha yüksek fide uzunluğu elde edildiği bildirilmiş olup, çalışma sonucunda elde ettiğimiz veriler ile benzerlik göstermektedir. Fide büyüme ve gelişmesini etkileyen önemli parametrelerden birisi de kök uzunluğudur. Çalışmada kök uzunlukları bakımından en yüksek değer $32.06 \mathrm{~cm}$ ile torf + perlit karışımından elde edilmiştir. Kök uzunluğu bakımından en düşük değer ise $21.73 \mathrm{~cm}$ ile torf ortamından elde edilmiş olup, kök uzunluğu bakımından torf ortamı, torf + toprak + perlit + kum ortamı $(23.73 \mathrm{~cm})$ ile istatistiksel bir fak oluşturmamıştır. Torf + perlit karışımı diğer ortamlara göre havalanma açısından daha avantajlı olduğu için kök uzunluğu bakımından üstün özellik sergilemiştir. Kök uzunluğu bakımından torf ortamı en düşük değeri vermiş olmakla birlikte kök hacmi bakımından en yüksek değeri vermiştir. $\mathrm{Bu}$ durum, torf + perlit ortamının havalanabilirliği ve su tutma kapasitesinin uygun olmasına rağmen az sayıda kök oluştuğu ve daha derine gidebildiği ile açıklanabilir (Yılmaz ve Kınay, 2016). Riaz ve ark. (2008), fide büyüme ve gelişmesi üzerine azot, fosfor ve potasyum gibi makro besin elementleri yanında yetiştiği ortamın yapısı, $\mathrm{pH}$ ve tekstür gibi fiziksel ve kimyasal özelliklerin etkili olduğunu ve yetiştirme ortamının fide büyümesi ve fide kalitesi üzerine önemine vurgu yapmışlardır. Atif ve ark. (2016), torf, kompost ve geleneksel uygulama ortamının birlikte karıştırılarak kullanılmasının fide gelişiminde en iyi sonuçları verdiğini bildirmiştir.

Adaçayı fide üretiminde kullanılan farklı yetiştirme ortamları, yaprak klorofil içeriği, kök yaş ve kuru ağırlığı ile fide yaş ve kuru ağırlığı üzerine istatistiksel olarak $(P<0,01)$ önemli etkide bulunmuştur (Tablo 2.). En yüksek yaprak klorofil değeri 36.63 ile torf ortamından, en düşük değer ise 32.53 ile torf + toprak ortamından elde edilmiştir. Yaprak klorofil değeri bakımından torf ortamı, torf + kum ortamı ile istatistiksel olarak aynı grup içerisinde yer almışlardır. 
Çizelge 2. Farklı yetiştirme ortamlarının adaçayı fidelerinde klorofil içeriği, kök yaş ve kuru ağırlığı ile fide yaş ve kuru ağırlı̆ı̆ üzerine etkileri

Table 2. Effects of different growth media of Sage (Salvia officinalis L.) seedlings on chlorophyll contents, fresh and dry weight of root and seedlings

\begin{tabular}{|c|c|c|c|c|c|}
\hline Ortamlar & SPAD & $\begin{array}{l}\text { Kök Yaş Ağ. } \\
\left(\text { (g bitki-1) }^{-1}\right.\end{array}$ & $\begin{array}{l}\text { Kök Kuru Ağ. } \\
\left(\mathrm{g} \mathrm{bitki}^{-1}\right)\end{array}$ & $\begin{array}{l}\text { Fide Yaş Ă̆. } \\
\left(\text { g bitki }^{-1}\right)\end{array}$ & $\begin{array}{l}\text { Fide Kuru Ağ. } \\
\left(\mathrm{g} \mathrm{bitki}^{-1}\right)\end{array}$ \\
\hline Torf & $36.63 \mathrm{a}$ & $3.48 \mathrm{a}$ & $0.57 \mathrm{a}$ & $3.48 \mathrm{a}$ & $0.84 \mathrm{a}$ \\
\hline Torf+Toprak & $32.53 \mathrm{c}$ & $2.82 \mathrm{~b}$ & $0.45 b$ & $3.43 \mathrm{a}$ & $0.68 \mathrm{~b}$ \\
\hline Torf+Perlit & $34.17 b$ & $2.79 \mathrm{~b}$ & $0.44 \mathrm{~b}$ & $3.08 \mathrm{~b}$ & $0.64 \mathrm{~b}$ \\
\hline Torf+Kum & $36.50 \mathrm{a}$ & $2.54 \mathrm{~b}$ & $0.33 c$ & $2.90 \mathrm{bc}$ & $0.63 \mathrm{~b}$ \\
\hline Torf+Toprak+Perlit+Kum & $32.90 \mathrm{c}$ & $1.98 \mathrm{c}$ & $0.27 \mathrm{c}$ & $2.63 \mathrm{c}$ & $0.54 \mathrm{c}$ \\
\hline Ortalama & 34.55 & 2.72 & 0.41 & 3.10 & 0.66 \\
\hline LSD (\%5) & 0.740 & 0.014 & 0.038 & 0.665 & 0.001 \\
\hline Tekerrür & 0.425 & 0.066 & 0.001 & 0.027 & 0.000 \\
\hline Uygulama & $11.309 * *$ & $0.875^{* *}$ & $0.041^{* *}$ & $0.381 * *$ & $0.035^{* *}$ \\
\hline Hata & 0.226 & 0.067 & 0.003 & 0.021 & 0.001 \\
\hline DK (\%) & 0.07 & 0.26 & 0.44 & 0.22 & 0.32 \\
\hline
\end{tabular}

$*: p<0.05, * *: p<0.01$; aynı harfle gösterilen uygulamalar arasında fark yoktur.

Yüksek humik oranına sahip olan vermikompostun bitki besleme, fotosentez, yaprakların klorofil içeriği ve farklı bitki kısımlarının element içeriği üzerine pozitif etkisinin olduğu Theunissen ve ark. (2010) tarafından bildirilmiştir. Yaman (2019), farklı yetiştirme ortamlarında yetiştirilen Amerikan asma anacı fidanlarının yaprak klorofil içeriğinin belirgin şekilde etkilendiğini bildirmiştir. Adaçayı fide üretiminde yetiştirme ortamı olarak kullanılan torf ortamından elde edilen kök yaş ve kuru ağırlık ile fide yaş ve kuru ağırlık değerlerinin diğer ortamlardan elde edilen değerlerden daha yüksek olduğu belirlenmiştir. Yetiştirme ortamı olarak kullanılan torfun fidelerin toprak üstü ve toprak altı aksamını iyi geliştirdiği Tablo 2'de görülmektedir. Çalışmada en yüksek kök yaş ağırlığı (3.48 g bitki-1) ve fide yaş ağılı̆ı (3.48 g bitki-1) torf ortamından elde edilmiştir. Kök ve fide kuru ağırlık bakımından en yüksek değerler sırasıyla $0.57 \mathrm{~g}$ bitki-1 ve $0.84 \mathrm{~g}$ bitki-1 olarak elde edilmiştir. Torf toprağın nem içeriğini muhafaza etmesi, havalanma kapasitesinin yüksek olması, besin elementi içeriğini arttırması, organik madde içeriğinin yüksek olması ve hastalık ve zararlı taşımaması nedeniyle güçlü ve kaliteli bir fide ve kök gelişimi sağlar. Genel olarak fidelerin tutma oranının yüksek olması kök gelişimiyle ilişkilidir. Yetiştirme ortamı olarak kullanılan torf, üstün fizyolojik ve biyolojik özellikleri nedeniyle kök gelişimi üzerine pozitif etkiye sahiptir ve tarlaya aktarıldıktan sonra tutma oranının artmasına yardımcı olur (Bhardwaj, 2014). Kök gelişimi ile fide tutma oranı arasında pozitif bir ilişki vardır. Torf ortamının kök gelişimi üzerine yararlı etkileri olduğu Nowak (2004), Abirami ve ark. (2010) ve Bhardwaj (2014) tarafından gözlenmiştir. Polat ve ark. (2017)'in Crimson Sweet karpuz çeşidinde farklı yetiştirme ortamlarının fide kalitesine etkisini araştırdıkları çalışmada, torf uygulamasının en iyi fide ve kök gelişimi sağladığını bildirmişlerdir.

Sonuç olarak, adaçayı (Salvia officinalis L.) tohumlarından elde edilen sonuçlar genel olarak değerlendirildiğinde; yetiştirme ortamı olarak kullanılan torf uygulaması, diğer uygulamalara kıyasla en yüksek çimlenme oranına ve en kısa çimlenme gün sayısına sahip olması yanında; fide uzunluğu, yaprak klorofil içeriği, fide yaş ve kuru ağırlığı ile kök yaş ve kuru ağırlığı değerleri verdiği için adaçayı fidelerinin büyümesi açısından da en iyi ortam olarak belirlenmiştir.

\section{ÖZET}

Amaç: Bu çalışmanın amacı, farklı altlık kullanılarak oluşturulan yetiştirme ortamlarının adaçayı (Salvia officinalis L.) tohumlarında çimlenme performansı ile fide kalitesi üzerine olan etkilerini belirlemektir.

Yöntem ve Bulgular: Araştırma 2020 yılında Niğde Ömer Halisdemir Üniversitesi Tarım Bilimleri ve Teknolojileri Fakültesi Bitkisel Üretim ve Teknolojileri Bölümü'ne ait uygulama serasında yürütülmüştür. Çalışma tesadüf parselleri deneme desenine göre üç tekrarlamalı olarak kurulmuş; yetiştirme ortamı olarak torf (\%100), toprak (\%100), perlit (\%100), kum (\%100), torf + toprak (1:1), torf + perlit (1:1), torf + kum (1:1), torf + toprak + kum + perlit (1:1:1:1) olacak şekilde sekiz farklı uygulama yer almıştır. Toprak (\%100), perlit (\%100) ve kum (\%100) ortamlarında sağlıklı fide gelişimi sağlanamamıştır. Çalışmada torf (\%100) uygulaması en yüksek çimlenme oranı (\%88.83) ve en kısa çimlenme gün sayısı (26.60 
gün) değerlerini vermiştir. Ayrıca, torf uygulaması en yüksek fide uzunluğu $(20.37 \mathrm{~cm})$, yaprak klorofil içeriği (36.63), fide yaş ve kuru ağırlığı ( $3.48 \mathrm{~g}$ ve $0.57 \mathrm{~g}$ ) ile kök yaş ve kuru ağırlığı (3.48 g ve $0.84 \mathrm{~g}$ ) değerlerine sahip olmuştur.

Genel Yorum: Adaçayında yetiştirme ortamı olarak kullanılan torfun diğer ortamlara kıyasla çimlenme ve fide gelişimi açısından daha etkili altlık materyali olduğu belirlenmiştir.

Çalışmanın Önemi ve Etkisi: Çalışmada elde edilen sonuçlara göre; farklı yetiştirme ortamlarının tohumların çimlenme ve fide-kök gelişimi üzerine etkisinin olduğu, bu nedenden dolayı sağlıklı ve kaliteli adaçayı fidesi üretmek için uygun ortamların belirlenmesinin önem arz ettiği ve en uygun yetişme ortamının torf olduğu çalışmada tespit edilmiştir. Sağlıklı ve kaliteli adaçayı fidesi üretmenin yüksek verimlilik adına önemli olması ve uygun ortamın belirlenmesi bu konuda çalışan üreticilere ve dolayısıyla tarımsal üretime katkı sağlayacaktır.

Anahtar Kelimeler: Salvia officinalis, torf, çimlenme oranı, SPAD.

\section{ÇIKAR ÇATIŞMA BEYANI}

Yazarlar çalışma konusunda çıkar çatışmasının olmadığını beyan eder.

\section{ARAŞTIRMACILARIN KATKI ORANI BEYANI}

Yazarlar çalışmaya eşit oranda katkı sağlamış olduklarını beyan eder.

\section{KAYNAKLAR}

Abacıoğlu E (2019) Adaçayı (Salvia officinalis L.) tohumlarında hormon uygulamalarının çimlenme ve fidecik karakterlerine etkisi. Yüksek Lisans Tezi, Kastamonu Üniversitesi Fen Bilimleri Enstitüsü, Kastamonu, $79 \mathrm{~s}$.

Atif MJ, Jellani G. Malik, MHA, Saleem N, Ullah H, Khan $M Z$, Ikram S (2016) Different growth media effect the germination and growth of tomato seedlings. Science, Technology and Development 35(3): 123127.

Bağdat RB (2006) Tıbbi ve aromatik bitkilerin kullanım alanları, tıbbi adaçayı (Salvia officinalis L.) ve ülkemizde kekik adıyla bilinen türlerin yetiştirme teknikleri. Tarla Bitkileri Merkez Araştırma Enstitüsü Dergisi 15(1-2): 19-28.

Bhardwaj RL (2014) Effect of growing media on seed germination and seedling growth of papaya cv. 'Red Lady'. African Journal of Plant Science 8(4): 178-184.
Başer HC (2000) Production of Salvia oil in Mediterranean countries. In: Kintzios, S.E., editor. Sage the Genus Salvia. Harwood Academic Publishers. Amsterdam:The Netherlands. pp. 263268.

Baytop T (1999). Türkiye'de bitkilerle tedavi. Nobel Tıp Kitapları, İstanbul. 480s.

Boyle TH, Craker LE (1991) Growing medium and fertilization regime influence growth and essential oil content of rosemary. Hort Science 26(1): 33-34.

Bozkurt IA, Soylu S, Kara M, Soylu EM (2020) Chemical composition and antibacterial activity of essential oils Isolated from medicinal plants against gall forming plant pathogenic bacterial disease agents. KSU Tarım ve Doğa Dergisi 23: 1474-1482.

Cardens MCA, Gomez IFR, Ronacancio VJF, Cordoba BC, Canola PW (2006) Growth analysis of standard carnation cv. 'Nelson' in different substrate. Acta Horticulturae 718: 623-630.

Çelebi M (2019) Effects of different growing media on the yield in tomato, cucumber and pepper, and on seedling in tomato. Journal of Tekirdag Agricultural Faculty 16 (2): 112-120.

Dharmveer Meenu Sood D, Aziem S, lqbal K, Hussain A, Mahato $S$ (2016) Effect of different growth media on seed germination and growth parameters of Angelica glauca edgev. Indian Forester 142(11): 1093-1099.

Hussain R, Younis A, Riaz A, Tariq U, Ali S, Ali A, Raza S (2016) Evaluating sustainable and environment friendly substrates for quality production of potted Caladium. International J. of Recycling of Organic Waste in Agriculture 6: 13-21.

Kaçar O, Azkan N, Çöplü N (2009) Effects of different rooting media and indole butryic acid on rooting of stem cutting in sage (Salvia officinalis L. and Salvia triloba L.). Journal of Food, Agriculture \& Environment 7: 349-352.

Kaya K, Sertkaya E, Üremiş i, Soylu S (2018) Determination of chemical composition and fumigant insecticidal activities of essential oils of some medicinal plants against the adults of cowpea weevil, Callosobruchus maculatus. KSU Tarım ve Doğa Dergisi 21: 708-714.

Kösa S, Karagüzel O (2012) Yetiştirme ortamlarının Alnus orientalis fidanlarının büyüme özellikleri ve yaprak besin elementi içeriklerine etkileri. Akdeniz Üniversitesi Ziraat Fakültesi Dergisi 25(1): 39-46.

Kusaksiz, G., (2019). Rare and endemic taxa of Lamiaceae in Turkey and their threat categories. Journal of Scientific Perspectives 3(1): 69-84. 
López Castro RI, Delmastro S, Curvetto NR, (2008) Spent oyster mushroom substrate in a mix with organic soil for plant pot cultivation. Micologia Aplicada International 20(1): 17-26.

Mossi AJ, Cansian RL, Paroul N, Toniazzo G, Oliveira JV, Pierozan MK, Pauletti G, Rota L, Santos AC, Serafini LA (2011). Morphological characterisation and agronomical parameters of different species of Salvia sp. (Lamiaceae). Brazilian Journal of Biology 71: 121129.

Polat S, Şahin N, Özdemir H (2017) Farklı fide yetiştirme ortamlarının Crimson Sweet karpuz çeşidinde fide kalitesine etkileri. Akademik Ziraat Dergisi 6: 47-50.

Riaz A, Arshad M, Younis A, Raza A, Hameed M (2008) Effects of different growing media on growth and flowering of zinnia elegans cv. blue point. Pakistan Journal of Botany 40: 1579-1585.

Sapar SN (2019) Farklı lokasyon ve dönemlerde alınan Salvia aramiensis Rech. fil. çeliklerinin köklenmesi üzerine IBA'nın etkisi, Yüksek Lisans Tezi, Hatay Mustafa Kemal Üniversitesi, Fen Bilimleri Enstitüsü, Hatay, $62 \mathrm{~s}$.

Sarıcı SÜ, Kul M, Candemir G, Aydın H, Alpay F, Gökçay E (2004) Adaçayı yağının yanlış kullanımına bağlı neonatal konvülziyon. Gülhane Tıp Dergisi 46(2): 161162.

Shahid A, Hussain R, Riaz A, Younis A (2017) Effect of different substrates on vegetative growth and quality of cast iron (Aspidistra elatior L.). International Journal of Biosciences 10(3): 297-308.
Theunissen J, Ndakidemi PA, Laubscher CP (2010) Potential of vermicompost produced from plant waste on the growth and nutrient status in vegetable production. International Journal of the Physical Sciences 5(13): 1964-1973.

Yaman E (2019) Farklı yetiştirme ortamlarının 5 BB Amerikan asma anacının fidan kalitesi ve randımanı üzerine etkisi. Yüksek Lisans Tezi, Ordu Üniversitesi, Fen Bilimleri Enstitüsü, $46 \mathrm{~s}$.

Yılmaz D, Gökduman ME (2015) Adaçayı (Salvia officinalis L.) bitkisinin farklı nem düzeylerinde fizikomekanik özelliklerinin belirlenmesi. SDÜ Ziraat Fakültesi Dergisi 10(1): 73-82.

Yılmaz G, Kınay A (2016) Goji beri (Lycium barbarum L.) fidesi üretimine farklı ortamların etkileri. Gaziosmanpaşa Üni. Ziraat Fakültesi Dergisi 33(1): 111-115.

Zawiślak G, Dyduch J (2003). The relation between seedling size and yield of sage (Salvia officinalis). Annales Universitatis Mariae Curie-Sklodowska. Sectio EEE, Horticultura 12: 1-7.

Zeybek U, Zeybek N 2002 Farmasötik botanik [Kapalı tohumlu bitkiler (Angiospermae) sistematiği ve önemli maddeleri. E.Ü. Eczacılık Fakültesi Yayınları., No:3 Bornova, İzmir, s.380. 